\title{
IDEA OF GOD OR GEOGRAPHY BETWEEN CHRISTIANITY AND ISLAM IN THE PERIOD OF THE MIDDLE AGES: REFLEXIONS ON THE EXAMPLE OF THREE CITIES
}

\author{
DOI: http://dx.doi.org/10.18509/GBP.2019.40
}

UDC: 91-05:28-05]:144.4(38)"653"

\section{Goran Mutabdzija}

Faculty of Philosophy, University of East Sarajevo, Pale, Bosnia and Herzegovina

\begin{abstract}
This paper analyzes the development of geographical thinking within the Mediterranean during the Middle Ages on the basis of three examples. When using these examples, the method of comparison and geographical method were used. Traditional interpretation emphasizes the renaissance takeover of geographical ideas as a result of the transmission of ancient geographical knowledge preserved by the Arabs, and then transferred to Europe [6]. At that time, geographers used four terms before they used the word geography as an indication of a special subject that deals with the earth. The four terms that Muslim geographers used were: knowledge of latitude and longitude, knowledge of country evaluation, knowledge of routes and kingdoms and knowledge of the strangers [1]. Geographic learning was a part of philosophical thinking [12] in addition to the destruction of some of the most important treasuries of ancient scientific thought, primarily Alexandria libraries, some of the most important works of ancient philosophers (e.g. Aristotle, Plato, etc.) have been translated by Palestinian monks to Syrian language. During the Islamic golden period $\left(8^{\text {th }}-12^{\text {th }} \mathrm{c}\right.$.), these books were translated into Arabic (e.g. Almagest) and the most important scientific center and the largest library of the then world was the House of Wisdom in Baghdad [5]. These texts were then translated from Arabic into Latin, making them widely available. The most famous center in the Arab world, where scientific works were translated into Latin, during the $11^{\text {th }}$ and $12^{\text {th }}$ century was the Aristotle School in Baghdad. [21].
\end{abstract}

Keywords: geographical thinking, Middle Ages, monotheistic religions, el-Mukadasi, alIdrizi, Maimonides

\section{INTRODUCTION}

In its origin, geography was a part of a wider philosophical thinking, within which the cosmogonic and cosmological performances were dominant. That is why it can be said that philosophy during the ancient period was filled with the idea of the world. At the beginning of the Middle Age, new central philosophical concepts (history and personality) were established, and the profane world was not given any hope, but only in "the other world". For Christians, it was the "kingdom of heaven", and for the Platonists it was the eternal "world of ideas" [13]. During the early centuries of the Christian era, geography was a fascinating mix of different geographical sources, and modern knowledge was composed mainly of traditional Christian elements. They came from reading the Bible and we learn about it from historical geography (mainly the geography of the Holy Land). Christianity first spread through Greek cities, and the consequences of this influenced the further development of the ancient science. Since there was a rejection of earlier knowledge and interest in science and rational geographic concepts, ancient 
ideas and geographical literature were preserved, mainly on the edges of the then Christianity [15]. During the medieval period, many of the ideas of ancient philosophy, and therefore geographical, were covered with a veil of ignorance and secrecy. This millennium period (from the fall of Rome to the discovery of America), however, did not remain completely unconscious of the achievements of the ancient philosophical thought [9]. In a certain way, we could say it implies also the annihilation of geography in itself, as it implies the idea that the knowledge of the Earth can be entirely delegated to philosophy and theology. Apart from some random attentiveness, in Middle Ages the relationship between philosophical and geographical knowledge is marked by a steady decline of geography as a science in itself [11]. Based on the development and exchange of geographical knowledge and philosophical ideas during the Middle Ages, and using the imaginative power of the geography of philosophy, we can imagine a wide area of contact between Christian Europe and parts of the Mediterranean under Islamic control. Clearly, three of the most significant geographical areas are recognized: the Pyrenees, the Sicily and the Crusader states in Asia Minor and Palestine.

In order to better understand the complex social relations in these regions, it is necessary first to clarify their general political and geographical framework. Today's Muslims living in these regions are mostly part of the numerous Arab ethno-linguistic groups of peoples who during the VII century accepted Islam, and then as an organized military force began to spread in the Mediterranean. The Arabs and Jews belong to the same group of IndoEuropean nations (Semites) who have lived together for millennia in Palestine, which in the ancient times was called Hanan. The coexistence of Muslims and Christians, in the other two regions, has a shorter historical period. The Arabs ruled part of the Pyrenees Peninsula for less than eight centuries, and in Sicily for about two centuries. Within these "zones of cultural radiation", there were urban centers of specific spatial structure, which enabled the interaction of different civilizations and the exchange of philosophical and geographical ideas. In order to show the development of geographical thinking more faithfully during the study period, we will analyze the works of three geographers - the philosopher (el-Mukadasi, al-Idrizi, Maimonides) whose work was related to the then largest and most advanced cities of this region (Jerusalem, Palermo and Cordoba) in which the greatest symbiosis of the three monotheistic religions (Judaism, Christianity and Islam) was realized and whose most famous architectural heritage (Old City, Palazzo dei Normanni, Mezquita) represented a guideline for all European science and culture.

\section{GEOGRAPHICAL AXLES OF THE WORLD: EAST-WEST}

It is necessary to emphasize, in addition to the significant influence of ancient philosophical thinking on the adoption of new geographic ideas, there was the spread of original geographical knowledge in the Arab world during the Middle Ages. This segment is often overlooked, and the origin of the geographical ideas in the Muslim world is multiple and is due to: religious reasons, everyday needs, trade, diplomacy and politics. Almost in all areas - astronomy, mathematics, medicine, optical - Arab scientists were among the leading in the world. For more than 600 years, the Arabs were technically and scientifically far ahead of the West, but the scientific revolution during the $16^{\text {th }}$ and $17^{\text {th }}$ centuries did not take place in the Middle East but in the West Europe. The reasons for this lie in free academic institutions with internal self-government, which was a feature of European universities [18]. This was also true for geographical learning. As an introduction to the main theoretical discussions on geography, it should be noted that among the earliest known scientists there were also those who dealt with geographical 
issues. Al-Asmai from Basra wrote about plants, animals and the evolution of human society, and al-Calbi was a historian in pre-Islamic Arabia who had observations and many geographical topics. Likewise, on agriculture, ibn Vahsiah, a al-Kindi, primarily a philosopher and physicist, wrote the geographical work "A Described Part of the Earth" [16]. However, the foundations of Arabic geographical science were set by al-Quarizmis, who wrote "Book of the Description of the Earth," a kind of syncretic text about the geographical knowledge of the Greeks and Hindus. He managed to improve Ptolemy's geography in both textual and cartographic terms. Nevertheless, his capital work "Keys of the Sciences" has a broader scientific significance, and the mentioned achievements were evaluated by contemporary European scientific thought as the highest point in the development of Muslim geography. In the geographical works at the time, new methods were developed and a critical attitude towards previous knowledge, primarily Greek, was developed and Aristotle's work was hugely influential in this period, and he was often referred to simply as 'the philosopher'. Many of the key developments in this period were the product of influences from Arab thinkers, such as al-Idrisi, whose reflections on geography and cartography were important for several centuries [4].

A good example is the former division of the known world based on climatic characteristics, where the division of heat waves is determined by the correct geometric lines that did not respect local geographic factors. Al-Istakri saw this, so he applied a regional approach to geographical study through the selection of geographical units that closely correspond, which explained this: "I do not take seven climatic conditions as the basis for the division of the country, because the geometric forms, although essentially correct, lead to a great confusion, so that I resorted to studying the Earth wisely" [22].

Based on this brief statement, we can clearly identify influence of Aristotelian philosophical thought on al-Istakri, which was based on the empiricism, experience of the existence of geo factors and local environment factors, and which modify climate zones. Abu Zaid Ahmad Sahl Balkhi (849-934) or al-Balkhi, was a widely known scholar who especially distinguished himself in cartography, and his work, as well as his students', was described by European scientists as an original Balkhi geographic school. "As a young man, he went to Iraq, where he studied various subjects for eight years. Together with the philosophy, Abu Zaid studied other Greek sciences such as medicine and physics, and was interested in astronomy / astrology. In this period it was unusual for students of philosophical or "foreign" disciplines to study Islamic discipline, but Abu Zaid combined both studies and gained a high degree of knowledge in both. It is possible that after eight years of studying in Iraq he traveled to neighboring countries, but he returned to Bal and became a teacher. At the beginning of his career, he wrote two theological books (Karmati and Dualists), in which he advocated Sunni views, although he was an imam. His biographers state that he wrote forty-three to fifty-six books, whose titles cover most of the fields he studied. Strangely, his book that ultimately became the most influential (Șowar al-aqālīm or Taqwīm al-boldān) is not clearly stated in any of his biographies. Although it did not exist as a separate book, it is contained in the geographical descriptions of Eșțakrī and Ebn Ḥawqal. These works were described by M. J. De Goeje, who studied in detail a second, significantly expanded edition of the Balkhi work. His geographical work was essentially a commentary on the maps of various "climates" (probably in Eștakrī meaning "provinces"). It seems that Balkhi has far outstripped the previous writings on geography, which was something more than providing information on the postal routes of the empire. Geography is now conceived as the inclusion of a description, and not only of the physical characteristics of countries, but also of their 
climate and natural characteristics and their impact on the structure and activities of the population. On such grounds, Balkhi was greeted as the founder of the classical school of Arabic geography" [20].

Al-Nadim and his capital work "Encyclopedia" have similar status. After these introductory remarks on the most important early Muslim geographers and their research pre-explorations, we will analyze the reasons that led to the spread of geographic knowledge. The most important motive, for most scholars, lies in the essence of Islam itself, because the journey to the hajj, pilgrimage to Mecca, is the duty of every capable Muslim at least once in their lifetime. Because of this, almost all early Muslim geographers put Mecca at the center of their interests, and as a goal of geographical study, they set up the itinerary to this sacred place for all Muslims. These instructions for travelers to the travelers contained a description of the area through which they passed, as well as numerous other useful information. That is why it is estimated that itineraries "were written from an administrative angle, but geographical discussions were always developed. They were usually concrete, accurate and detailed" [14].

Therefore, the most numerous part of geographical files had a regional geographic character. This is testified by numerous geographical stories and debates $\left(8^{\text {th }}-10^{\text {th }} \mathrm{c}\right.$.) and the most famous pilgrims from this period were Mohammed al-Andalusi (Spain) and Al-Tidjani (Tunisia). The aim of the trip was the quest for religious knowledge, which depended on the immediate oral tradition, for which scientists traveled for a long time and wrote about it. Practical reasons have also led to the development of Islamic geography, which is related to general and regional geography. Ibn Rusta described the most basic astronomical and topographical terms, and Ibn Kurdadih wrote a book of roads and provinces for the purpose of postal traffic. Nevertheless, trade with China was one of the main factors that spurred Islamic geographical and nautical knowledge, resulting in the first descriptions of China made by Arab traders. Al-Jakubi wrote the "Book of Countries" and, probably, the first Arabic work on historical geography, describing almost the entire Islamic world, the Byzantine Empire, India, and China. Diplomacy and Politics also encouraged the spread of geographic knowledge. Al-Gazal's journey to Scandinavia is known and the rulers of North Africa and Spain sent two ambassadors to the German emperor in Magdeburg. Their reports contain valuable information on the "coastal cities of France, the Netherlands, Germany and the Kingdom of the Slavs". Also, there are records of diplomatic missions to the eastern parts of Islamic states, for example, Bukhara, Kashmir, Tibet, Afghanistan and southern India.

Al-Masudi (896-956) was an Arabic geographer and historian and is often called the Arab Herodotus. He made unavoidable contributions to Muslim geography, history and philosophy, and in his main work "Golden Fields and Precious Stones" described the political and cultural history of the Islamic world. All of these missions contributed to the spread of the horizon of geographical knowledge in the Islamic world, which corrected earlier performances and made it possible to transfer this knowledge to Europe. His statue is on the roof of the Natural History Museum in Vienna, among the greatest scientists who have indebted the world of natural sciences. Of great importance were Muslim travel writers from the period $9^{\text {th }}-14^{\text {th }}$ century who expanded the geographical representations of the Earth, but also contributed to the exchange of this knowledge with the Europeans. Such was the al-Idrisi, who lived at the court of the Norman king of Sicily. And ibn Butut traveled the entire Islamic world, more than his contemporary, Marc Paul, and translated his impressions into the book "Rihla" (Travel). Ibn Haldun was more a historian, and his 
most famous work "Mukadema" (Introduction) is considered to be the forerunner of contemporary sociology.

In addition to these geographical consequences, which resulted from the very purpose of travel, the great importance in spreading geographical knowledge had practical skills and knowledge that resulted from everyday religious practice. The compilation of the prophetic utterances also influenced the accuracy and precision of Islamic geography, and the benefit was reflected in the knowledge of the local environment and mathematical geography, especially in the domain of determining: the direction towards the cave in Mecca (this direction denotes the position of the mihrabb niche in each mosque and all Muslims must turn in this direction during prayer), geographical coordinates for the exact local time (five daily prayers) and so on.

\section{JERUSALEM: THE LIGHT ON THE DOME OF THE HOLY CITY}

The term Crusader states refers to four feudal states formed by crucifixes in Asia Minor and Palestine, and after their first conquer of the Holy Land (1096-1099). These principalities briefly retained autonomy (from 52 to 191), and then they were occupied again. The first of them was Edessa (today's Urfa, located in the province of Chanliurfa in the southeast of Turkey). The Principality of Antioch was a neighboring region in northern Syria and southwestern Turkey. Today, this term reminds us of the Antiochian Patriarchate, one of the four ancient patriarchates of the Ecumenical Patriarchate of Constantinople, which, according to the tradition, was established by the Apostles Peter and Paul around 37 AD, in Antioch (today's Antiquity in the Turkish region of Hatay). From the Antiochian church, many holy saints and leaders of Orthodoxy come from John Chrysostom, John of Damascus, Hilarion the Great and many others. The Count of Tripoli was located in today's northern Lebanon and western Syria, and in ancient times it was the center of Phoenicia. The kingdom of Jerusalem was the longest and contained four vassal territories: Galilee, Jaffa and Askalon, Sidon and Transjordan. In a wider sense, these states belong to later established principals, Cilicia or Small Armenia, located in southern Turkey (capital Tarsus) and Cyprus.

A city that best reflects all the challenges of the historical endeavor and conflict of the various civilizations on earth is, of course, Jerusalem. It is a sacred city for three monotheistic religions (Judaism, Christianity and Islam) and is now in the state of Israel. It is considered sacred because in his Old Town there are some of the greatest sacred places for members of these religions. For the Jews, it was Solomon's temple, located on the Temple Mount. Twice it is demolished (Babylonians 586 BC and the Romans 70 AD), and today only the western wall remained (Wailing Wall). For Christians, the most sacred place on earth is the Golgotha Hill, on which Jesus Christ, the son of God, "died for all people" and then resurrected and pointed to "eternal life". The path that Jesus walked on the way to his crucifixion, passes through the narrow streets of the Old Town, is called the Way of Salvation (Via Dolorosa), and ends on the site of his suffering where the church of Christ's grave is located today. For the Muslims, this is Haram al-Sharif, a plateau from which, according to the legend, Prophet Muhammad "waded to heaven". There are now the mosques of the Dome on the rock and Al Aqsa (the same location on which Solomon's Temple was located on the Temple Mount). All the dramatic years of the millennium and the conflict of these civilizations can be described as follows:

"He stayed another hour before the feast day in Jerusalem. The dome on the wall is open; Muslims are praying. Church of the Holy Grave is open; Christians pray in several languages. The sun is rising over Jerusalem, under its rays, the bright Irodian stones of 
the Wall look almost as if under the snow - just as Joseph Flavius described it two thousand years ago - the rays then fall on the magnificent golden Dome on the wall, which returns the reflection to the sun. The divine gaze encountered by Heaven and Earth, where God meets with man, is immutable in a kingdom that evades human cartography. Only the sun's rays can do this, and finally, the light falls on the most refined and mysterious building in Jerusalem. Splendid and sunbathing, deserves its sacred name. But the Golden Gate remains locked until the last days. (...) Jewish believers believed that two preconditions for the coming of Judgment Day were fulfilled: Israel was restored, and Jerusalem belonged to the Jews. The only other thing is just to raise the Third Temple and to pass seven years of suffering, followed by the Battle of Armageddon, when Archangel Michael appears on the Mount of Olives in order to fight the antichrist on the Temple Mount. The highlight of these events will be the conversion or destruction of the Jews and the Second Coming and the Thousand Years of the Ruling of Jesus Christ" [8].

For a more complete understanding of the geographical specifics of Palestine and Jerusalem, the best example provides an insight into the life and work of the Arabic geographer el-Mukadasi who lived in X c. He traveled a lot and was a prolific writer, and all he wrote was the fruit of his own observations during travels, from the description of countries to national customs. M Shah tells him to "bear the seal of a smart and cautious mind, which is determined by profound knowledge of both books and people." The most famous work of el-Mukadassi is "The best division for the purpose of introducing the region: The Great Books of Islamic Civilization" in which he "divides the Islamic world into fourfold" eklima" (climate or region); then, he deals with each region separately. He divided his work into two parts, first listing localities and providing adequate descriptions for each, especially the main urban centers. Then, it switches to other subjects: population, ethnic diversity, social groups, before moving to trade, mineral resources, archaeological monuments, currencies, weights, etc. but also to the political environment. This approach is contrary to his predecessors, whose focus was much narrower, while el-Mukadassi wanted to encompass aspects of interest to merchants, travelers and people of culture "[19].

His second book is "Palestine under the Muslims: Description of Syria and the Holy Land from 650 to 1500". This is a more interesting topic for us, because in it the author gives a significant description of Jerusalem, his hometown. At the same time, this is one of the best and most interesting parts of this extensive book (604 pages), which is divided into two parts and nine chapters. Jerusalem is described in the third (name, position, advantages), the fourth (Haram and Omar's mosque) and the fifth chapter (the gate of the Old Town and the Church of Christ's grave). The interest and beauty of his speech can be seen in the chapter on the Omar conquests: "Al Valid referred to the authority of Said ibn Abd al-Aziz, that the Prophet's letter came to Caesar while he was in the Holy City. At that time, there was a bundle of trash on the Temple Mount that completely covered the place where Solomon's temple was, which was done by Christians to offend the Jews, because even the Christians did not want to throw their clothes, so everything seemed to collapse. When Caesar read the prophet's letter, he cried out and said: "Oh, you Greeks, you are likely to be killed on this dirt, because you have despised the sanctity of this place, and it will be with you, as it was with the children of Israel, who were killed for the blood of Yahweh and Zacharias. "Then Caesar ordered that they clean this place, and they began to work; the Muslims conquered Syria, only a third of them were cleared. When Omar came and conquered the Holy City and saw the dirt on the Temple Mount, he considered it terrible and ordered that this be completely cleansed. In order to do so, they forced the 
Palestinian Nabatians to do it without pay. According to Jabir ibn Nafir, when Omar saw the Temple Mount, he ordered that they should not pray to the god until three heavy rains fall" [3].

From this brief review of his work, a wide regional-geographical approach to the study of specific areas is visible, which was a feature of the aforementioned Balkhi-style or the classical geographic school, of which he was a prominent representative. His geography is no longer a traditional one, but a work that attempts to understand and explain the social foundations and functioning of Islamic society. From this, you can get excellent information on many topics, such as; cities and town development, water management, etc. As a well-known historical figure, he was among the first to identify himself as a Palestinian.

\section{PALERMO: THE ARABIC MOSAICS OF VIZANTIAN - NORMAN GLOW}

Sicily has a central position in the Mediterranean and during its cultural history was the bridge between different civilizations within this region. As Crete was a sort of stop-site for nations / cultural groups from Egypt and Mesopotamia in the Ancient World, Sicily has been a "stepping stone" for powerful cultures that wanted to conquer the Apennine Peninsula or southern Europe since the ancient times. A replica of these historical events is being watched today in the waters around Sicily, only now on an individual plan, through an attempt to achieve personal ambitions, many residents of African countries are trying to replace the place of residence with a new European address. These conquests have begun with the establishment of the first Greek colonies (Syracuse, Agrigento), and the ambition to conquer Sicily was with the Carthaginians and various Germanic tribes (Goths, Ostrogots, Vandals). After the Byzantine Empire, which lasted for almost three centuries, Sicily was conquered by the Saracens (Arabs) in the $9^{\text {th }}$ century. Over the next two centuries, they will rule the island and in its cultural landscape will unite many elements inherent in their culture, from subtropical fruit to numerous religious sites. The Norman conquest of Sicily in the second half of the $11^{\text {th }}$ century brought about a serious change in the spatial structure; from the solid structure of the Oriental city began to form the outlines of new Mediterranean forms. One object saved its purpose, but significantly changed its form. Kasr (Qasr), the seat of the Sicilian emirs, disappeared, and the residence of the Norman kings were created. During the reconstruction of one building, not only a sophisticated building was built for the same purpose, but for another master. A new architectural style was created, representing the synthesis of previous experience and new practice: the Byzantine-Arab-Norman style was created, the Norman Palace with Palatine, a chapel that is a masterpiece of the then decorative art of different styles, and today represents the most important trace of that time. It has a harmonious combination of elements of Norman architecture, especially visible on the entrance portals, Arabic arches and ceiling decoration and the Byzantine dome and numerous mosaics. This particular style lasted only two centuries in the public life of Sicily, i.e. while there was a balanced relationship between the various ethnic groups that were reflected the character of the three civilizations: Norman-Catholic, Byzantine-Orthodox, and Arab-Muslim.

Previously, all the potentials of these communities have been exploited for the general progress of the new kingdom. This was evident in a wide range of areas, from the application of advanced elements of Arab agriculture to Byzantine culture, including architecture and direct translations of classical Greek texts into Latin. Based on such a clever approach, which is reflected in the fact that former adversaries became useful 
members of society, and not exclusively enemies to be expelled, Sicily will become the dominant state and expand into southern Italy.

Almost half of the $13^{\text {th }}$ century is spoken by most of the population in Latin, and under the influence of the assimilation of the minority ethnic community, the Greeks and the Arabs are slowly disappearing. This becomes a universal pattern of utilitarian morality that will become widely accepted, and is especially visible today. It then referred to the form of tolerance of the majority community towards the material heritage of minority communities, but not to the traces of their spiritual culture. By the Norman conquest of Sicily, all Islamic religious objects will disappear overnight, but artists and traces of Islamic culture will remain in public buildings. In the circumstances of the new cultural environment, Arabic artists will begin the creation of church mosaics with Biblical motifs instead of dealing with calligraphy and making decorative floristic motifs in former mosques. Four centuries later, by the fall of Constantinople, all its architectural values did not disappear, but all the Byzantine churches were converted into mosques. Today, only three former Orthodox churches that have been converted into museums are testimony to this: Hagias Sophia, Hagias Irene and The Church of the Holy Savior in Chora. There are numerous examples in contemporary history in our area, from the demolition of all Islamic buildings in the Pannonian plain after the Second Siege of Vienna (1683-99) or the demolition of religious buildings during the last civil war in Bosnia 1992-95 [10].

Palermo is a city of imposing architectural buildings. What distinguishes Palermo from other Renaissance cities is the old Cassaro road that runs from the sea coast, from Porta Felice and via Port Nuova, in the right line to the foot of Monreale $(4.3 \mathrm{~km})$, on top of which is the beautiful Norman cathedral with numerous mosaics. This is one of the most successful examples of Renaissance in the field of urban prospects on the European soil. Many of the key developments in this period were the product of influences from Arab thinkers, such as al-Idrisi, whose reflections on geography and cartography were important for several centuries [4]. The spirit of the multiethnic Palermo from the $12^{\text {th }}$ century and the fresh geographical ideas of Sicily, is best reflected by the al-Idrisi, whom Roger II, the then ruler of Sicily, charged with producing a book on geography. He worked for fifteen years, and the result of this work is the map of the world Tabula Rogeriana and the book of Roger, which explains the "pleasant trips to distant countries" and represents the most comprehensive and detailed geographical work written during the $12^{\text {th }}$ century in Europe. Al-Idrisi provides a brief astronomical description of the Earth, a globe with a circumference of approximately $37,000 \mathrm{~km}$ (error $<10 \%$ ), and the Earth's position in the universe is compared with egg yolk. The map was made on the principles of Ptolemy Cartography, divided into seven climate zones, each divided into ten parts. Each section is described in detail and illustrated with a separate card, and when all the cards are compiled, they represent a rectangular map of the world. It shows the Eurasian continent in its entirety and only the northern part of Africa. From this time distance, the book and map making methodology is particularly interesting. In order to collect quality information, the author used several sources. He was critical of traditional sources and collected a large amount of data for his map, not only from modern research, but also from charts and book navigation directions. He also interviewed numerous passengers, processed their statements in a way that he accepted only those parts that were not at all controversial, and excluded those who were least contradictory. The book contains all the available information about the geographical coordinates of cities, their distances and locations within the climate zones, and the text includes exhaustive descriptions of 
physical, cultural, political and socio-economic conditions of each region. The map is of opposite orientation, with the north at the bottom of the map, and the text is written in Arabic, so this was the most accurate map of the world over the next three centuries. Roger II put this map on a silver disk weighing about $180 \mathrm{~kg}$. His work has been commented on as: "A compilation that marks an era in the history of science, not only is its most interesting and valuable historical information, but its descriptions of many parts of the country are still authoritative." Geographers copied this map for three hundred years without modification. The position of the lake that forms the Nile, as explained in his work, does not differ much from what Baker and Stanley found more than seven hundred years later, and their number is the same. His erudition and knowledge of the celestial and Earth's planisphere in silver, that he made for his patron, the Sicilian king, was almost two meters in diameter and weighed about $180 \mathrm{~kg}$. On the one hand, they were engraved zodiac and conjuncture, and on the other, divided for the sake of transparency in segments - land and water masses with the corresponding position of different countries" [15].

In his work, al-Idrisi combined the geographical elements of the East and the West with Arabic knowledge in order to create a picture of the famous world, including main crops, the arts, and crafts, the export and import trade, and the customs, curiosities and religions of the people living within each of the seven climates into which he divides the world [17]. He also contributed to the Sicilian enthusiasm for geography that indirectly influenced the evolution of geographical knowledge in the post-Crusade period. This enthusiasm was a product of the mixing of Arabic scientific traditions with Norman maritime performances on the island that occupied a central position in relation to the then known world. It was an enthusiasm, which appeared in part, from pure love for knowledge, but also practical navigation needs.

\section{CORDOBA: MAIMONIDES UNDER THE ORANGE OF MEZQUITES' SHADE}

Part of today's Spain under the control of the Moors, from 711 to 1492 , is called Al Andalus. This term is wider than today's Andalusian region and covered, throughout the Zenith of Maury, almost the entire southern and central part of the Pyrenees Peninsula, approximately to the line of Porto-Madrid-Barcelona, and the most important cultural centers were Cordoba and Seville. The size of those cities at that time, is best shown by the analysis of urban centers in Europe in the period from 800-1400, based on which the city of Cordoba had 160,000 inhabitants in the year 800 (the largest was Constantinople with 300,000 inhabitants), and two centuries later they equaled the number of inhabitants - 450,000 [10]. The largest cultural significance in that period was given to the Mezquita mosque, an object in which the exchange of scientific knowledge and ideas was carried out. Even today, this ambient provides a remarkable impression on the viewer. As soon as you cross the Roman bridge over Guadalquivir, you come up to the walls of a large object whose function is difficult to determine. Only by entering into its interior, you see a small part of the beauty of this temple / mosque, which was built on the foundations of a church that previously stood there. It has been expanded three times and has become the largest mosque in the world, but its size is not the only thing that made it unique. First of all, it is a covered vault with more than 800 beautiful and richly decorated pillars of various shapes. It is also a mihrabb (a niche in the interior that faces the cave in Mecca) and represents the perfection of Islamic decorative artisticists, but above all, these are its structural elements (broken arch, counterfoils and gable vaults), which will later serve as an inspiration for the emergence Gothic architectural style. Given that Cordoba was then 
one of the largest European cities, and the Cordoba caliphate one of the most advanced in the entire Islamic world, it is clear that this has become one of the most important points in intercultural dialogue between Europe and Africa, between Christianity and Islam. Mezquita then represented a kind of university, in which, under numerous stone arches or shade of orange trees (patio), translations of ancient philosophical texts took place, a dynamic intellectual debate took place among the greatest philosophers of that time, but also the most talented students were taught there.

One of these philosophers will be Moses Maimonides, a "renaissance mind," which was said that "Moses (Abram) to Moses (Maimonides) did not have a similar Moses". He was a rabbi, he knew the principles of astronomy and mathematics, and worked as a physician in the $12^{\text {th }}$ century. After the Berberic conquest of Andalusia (Almohadi), the persecution of non-Muslims began, so Christians and Jews had to choose a new status (conversion to Islam or exile). At the age of thirteen, he leaves his native Cordoba and starts a long wandering and a struggle for survival. For around ten years, he hid in southern Spain, where he wrote his first philosophical works, and then moved to Tunisia. He lived briefly in Fes, he was under the tremendous pressure of Almohadi, as well as most of his compatriots who converted to Islam. For the purpose of their encouragement and desire to save his community from complete disintegration, he wrote a fierce discussion of the " The Epistle to Yemen ", which emphasizes the importance of daily prayer, even in the Arabic language, and that the forcible acceptance of the second faith does not constitute a desecration of the divine name. In order to avoid execution, he escaped to the Holy Land (Erec Jisraeli), which he will have to abandon because of the terrorist crusade, and after coming to Fustat (Cairo), he will have a peaceful and very fruitful period in his life and work. In Alexandria he will study Aristotle's work, and out of urgency, he will begin to study the field of medicine. In this field, he achieved such success, that he received an invitation from the King Richard of the Lion Heart to be his personal doctor, but he declined the offer and moved to the court of Sultan Saladin. He became stubborn, achieving numerous political concessions for his compatriots, including the approval of the Jews to settle in the Holy Land. That meant more obligations, which he said:

"Know my son, that in our difficult times, I do not consider, in any way, any honor or public position of happiness or honor; On the contrary, this is not only a small accident that can hit a man, but a great effort and burden that carries a lot of care and responsibility. The right man, who seriously strives for the bliss of the soul, takes care of his mental development and fulfillment of his moral duties and is kept away from the petty and low works of human vanity. Whoever wants to rule, it multiplies its worries and troubles" [7]. In his opus, there are relatively few elements relating to geographic ideas, which concern certain cosmogonic performances and astrology, which he developed under the influence of Aristotle's teaching. Also, the undoubted contribution to the spread of geographical knowledge is his experience as a large passenger and polyglot, and in methodological terms, special attention is drawn to his logical thinking and belief in scientific experiments, which he predominantly expressed through medical work. From philosophical and religious works, more attention is drawn to three papers. The first is the "Commentary of Mishneh" in which he addressed the principles of biblical and Talmudic legislation and the basic principles of Judaism. The greatest value of this work is in the domain of major theological questions, and it refers to the thirteen religious principles each Jew must believe. The greatest glory to Maimonides brought the work of Mishneh Torah (The Hard Hand) in which he systematically described Jewish laws in the field of faith, family life and social relations, and brought together the organic whole of the 
religious and legal decisions of the Talmud through philosophical observation and spiritual work. In the end, it is also a "The Guide for the Perplexed", which besides what it should "... enlightens a religious man who believes in the truth of our Holy Law, who consciously fulfills his moral and religious duties, and at the same time is successful in his philosophical studies ... it is an attempt to explain certain unclear figures that appear in prophecies, and they are not clearly marked as figures. Inattentive and superficial readers see them literally, not in the figurative sense. Even well-informed people are confused if they understand these passages in their literal meaning, but they are completely free of their doubts when we explain this picture or just hint that the terms are figurative. That's why I called this book The Guide for the Perplexed" [2].

The simplest summary of Maimonides's teaching, in modern light, can be seen through the statement that "his ethics were based on faith in the freedom of man's will and his work. For him, Aristotle was the greatest philosopher, and he tried to bring faith into harmony with the principles of ancient philosophy. The Mishneh Torah is his most famous book, one of the more important works of Judaism from the Middle Ages, which explains in detail all Jewish beliefs, including those laws that apply only when the Holy Temple exists" [7].

\section{CONCLUSION}

During the Middle Ages there was a break in the development of the geographical (philosophical) thinking, that begun in the ancient Greek period. Muslim geographers will, for pragmatic reasons, preserve and improve the elements of ancient geographical representations, as a framework for the development of medieval geographic thinking. The gates of knowledge, between the east and the west, will become Jerusalem, Cordoba and Palermo. They will, as some of the most advanced European cities of that time, create the most important works of the world's cultural heritage, as well as significant geographical works that will introduce more precision and brightness into the travelogue character of the geographical horizon. For expansion of geographical representations, it will be necessary to wait for Henry the Navigator (XV c.), who will bring much more systematic and organization into research trips, and to break with the cosmogoniccosmological representations of Aristotle's philosophy and Plato's geography, will be credited with Nikola Copernicus (XVI c.), the viceroy of the scientific revolution, and thus the establishment of assumption

\section{REFERENCES}

[1] Al-Monaes, W. A. Muslim contributions to Geography until the end of the 12th century AD. GeoJournal, Germany, vol. 25, pp. 393-400, 1991.

[2] Belić-Koročkin-Davidović, M. i Davidović, R. Majmonides-sećanje na njega trajaće večno, Serbia, 2018.

[3] El-Mukadasi. Palestine under the Moslems: A description of Syria and the Holly Land from a.d. 650 to 1500 (Translated from the works of the medieval Arab geographers by Guy de Strange). The Committee of the Palestine Exploration Fund, Canada, 1890.

[4] Elden, S. Philosophy and Human Geography, Durham University, UK, 2009.

[5] Glacken, C. Traces on the Rhodian Shore: Nature and Culture in Western Thought from Ancient Times to the End of the Eighteenth Century, USA, 1976.

[6] Livingstone, D. The Geographical tradition. USA 1992. 
[7] Maimonides, M. The guide of the perplexed. An abridged edition with introduction and commentary by Julius Guttmann. USA, 1935.

[8] Montefjore, S. S. Jerusalem - biografija. Serbia, 2012.

[9] Mamford, L. Grad u istoriji. Serbia, 2001.

[10] Mutabdzija, G. Regional Geography of Europe, USA, 2018.

[11] Papa, E. C. S. Philosophy and Geography. Journal of Interdisciplinary history of ideas, Italia, vol. 6 (12). pp. 1-9. 2017.

[12] Pakistan Philosophical Congress, Pakistan, vol. 2 (5), ch. 62, 2007.

[13] Rasel, B. Istorija zapadane filozofije, Serbia, 1998.

[14] Sarton, G. Introduction to the History of Science. USA, 1962.

[15] Scott, S. P. History of the Moorish Empire, USA, 1904

[16] Gutierrez, E. A. The Age of Light: An Overview of Arab Geography in the Middle Ages.USA, vol. 37 (1) pp.1-11, 1990.

[17] Unwin, T. The Place of Geography. USA, 1992.

[18] Širbek, G., Gilje, N. Istorija filozofije - od antičke Grčke do savremenog doba. Serbia, 2017.

[19] Tibbetts, G. R. Balkhī School of Arab Geographers, Encyclopaedia of the History of Science, Technology, and Medicine in Non-Western Cultures. Netherlands, 2008.

[20] Watt, . W. M. Abū Zayd Balkī, Encyclopædia Iranica, Iran, vol. I/4, pp. 399-400, 1982.

[21] Withers, C. W. J. The Enlightenment and Geographies of Cosmopolitanism. Journal of the History of Ideas, USA, vol. 70, (4), pp. 637-658. 2009.

[22] Zaimeche, S. A review of Muslim Geography. UK, pp. 1-13, 2002. 